\title{
Forecasting the financial results of the agribusiness company
}

\author{
Olga Novichkova ${ }^{1, *}$, Olga Tagirova $^{1}$, Alexey Nosov $^{1}$, and Marina Fedotova ${ }^{1}$ \\ ${ }^{1}$ Penza State Agrarian University, 440014, 30 Botanicheskaya Str., Penza, Russia
}

\begin{abstract}
Competent management of the company's activities is largely determined by the ability to manage financial results, analyze the features of their formation, which ensures the effective functioning of the organization. Timely analysis allows to study development trends, deeply and systematically examine the factors of changes in activity results, justify plans and management decisions, monitor their implementation, identify reserves for improving the efficiency of economic activity, evaluate the results of the enterprise, and develop an economic strategy for its development. For commercial enterprises, the main criterion for performance assessment is the financial result. At the same time, not only the goals and objectives of the company are multiple, but also the methods used by specialists in planning of the financial results formation. The quality of management of financial results largely determines the effective operation of the company, the stable pace of its work and competitiveness in modern economic conditions.
\end{abstract}

\section{Introduction}

Financial results of business entities are the main indicator of successful economic activity aimed at a long period of time. In an unstable economic situation, it is necessary to carry out a forecast analysis of financial results in order to make adequate and timely management decisions on the development of agricultural companies.

More than 150 large and medium-sized companies are engaged in agricultural business in the Penza region. Special attention is paid to the self-financing capabilities of agricultural enterprises. $[1,2,3]$. Over the past five years, there has been a downward trend in the net profit of regional farmers, which negatively affects the development of the agricultural sector and the ability of companies to develop more dynamically. This situation is associated with many internal and external factors. The most significant internal factors are primarily the volume of products produced and their production cost. On a regional scale, it is difficult to identify trends that affect the level of costs and, as a result, the level of profit, so we chose one of the large agricultural enterprises (Pachelmskoe Khozyaistvo LLC, which is part of Rusmolko GC), based on the economic activity of which we will study the features of financial results formation.

We will analyze the dynamics of gross profit, as well as the share of cost in the revenue of Pachelmskoe Khozyaistvo LLC for 2015-2019 in table 1.

\footnotetext{
*Corresponding author: novolka@mail.ru
} 
Table 1. Dynamics of gross profit and costs in Pachelmskoe Khozyaistvo LLC for 2015-2019.

\begin{tabular}{|l|c|c|c|c|c|c|c|}
\hline \multicolumn{1}{|c|}{ Indicator } & $\mathbf{2 0 1 5}$ & $\mathbf{2 0 1 6}$ & $\mathbf{2 0 1 7}$ & $\mathbf{2 0 1 8}$ & $\mathbf{2 0 1 9}$ & $\begin{array}{c}\text { 2015- } \\
\mathbf{2 0 1 9}\end{array}$ & $\begin{array}{c}\mathbf{2 0 1 8} \\
\mathbf{2 0 1 9}\end{array}$ \\
\hline $\begin{array}{l}\text { Revenue, thousand } \\
\text { rub. }\end{array}$ & 1900384 & 2252233 & 2750871 & 3260453 & 3756052 & 1855668 & 495599 \\
\hline $\begin{array}{l}\text { Cost of sales, } \\
\text { thousand rub. }\end{array}$ & 1693535 & 2035130 & 2379586 & 2895930 & 3391687 & 1698152 & 495757 \\
\hline $\begin{array}{l}\text { Gross profit, } \\
\text { thousand rub. }\end{array}$ & 206849 & 217103 & 371285 & 364523 & 364365 & 157516 & -158 \\
\hline $\begin{array}{l}\text { Cost share in sales } \\
\text { revenue, \% }\end{array}$ & 89.12 & 90.36 & 86.50 & 88.82 & 90.30 & 1.18 & 1.48 \\
\hline
\end{tabular}

Data of Table 1 indicate that the formation of gross profit in the economy has a positive trend, the profit from sales also increases from year to year. However, for 2015-2019, gross profit increased by 157516 thousand rub., and for 2018-2019-decreased by 158 thousand rub. To a large extent, this was negatively affected by the increase in the share of cost in sales revenue - for 2015-2019, this indicator increased by 1.18 percentage points, and for 2018-2019 - by 1.48 percentage points. These facts indicate that the cost of sales is growing at a higher rate than revenue. Since in 2019 , the main contribution to gross profit was made by sales of crop production, the main attention should be paid to this branch of production of Pachelmskoe Khozyaistvo LLC.

Sugar beet does not take the first place in the structure of profit from sales of crop production. However, it is sugar beet that has a good potential to increase profits. Figure 1 shows the dynamics of changes in the main indicators for the sugar beet production in Pachelmskoe Khozyaistvo LLC.

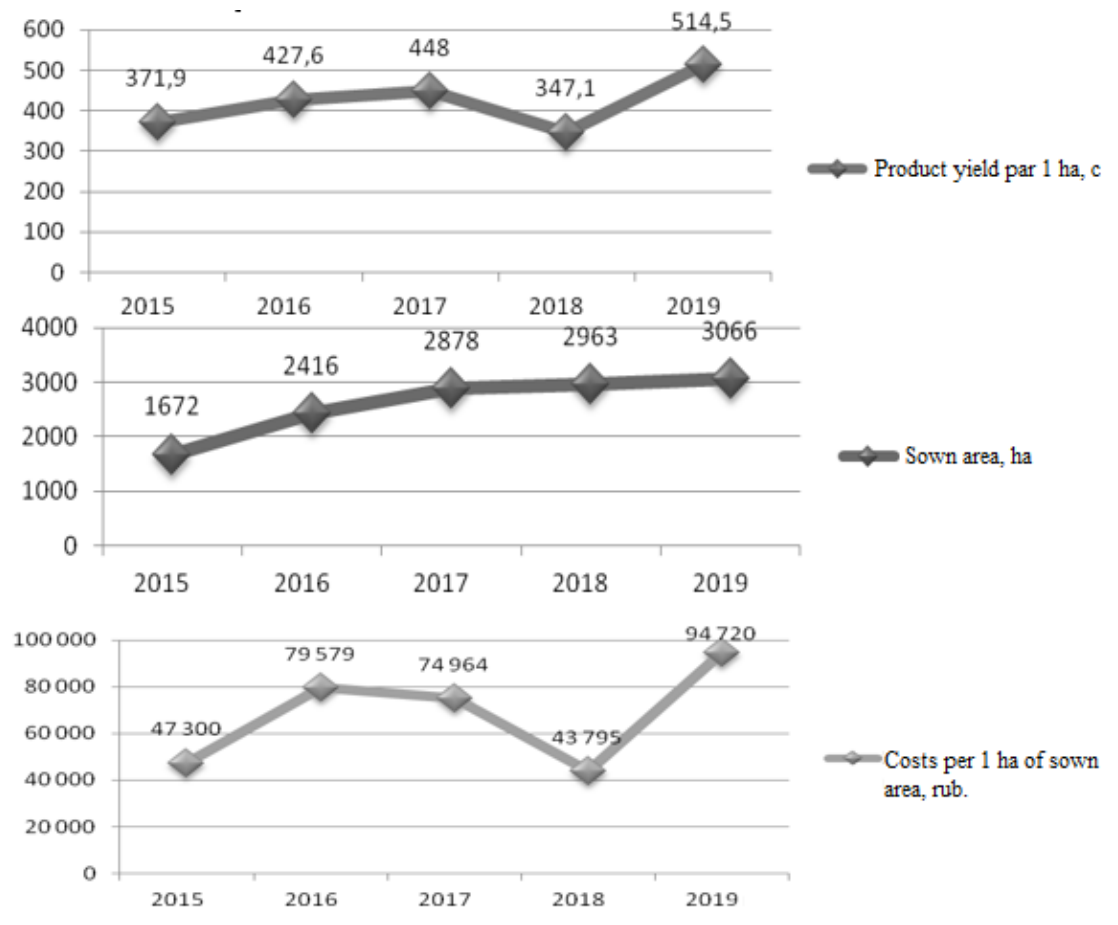

Fig. 1. Dynamics of changes in the main indicators for the sugar beet production in Pachelmskoe Khozyaistvo LLC for 2015-2019. 
The data in figure 1 show a significant increase in the acreage for sugar beet in Pachelmskoe Khozyaistvo LLC - almost 2 times over the analyzed period, and there are also significant fluctuations in costs per 1 ha of sown area for sugar beet, especially in 2018-2019 - from 43795 rub. in 2018 to 94720 rub. in 2019.

Therefore, it is worth paying attention to the peculiarities of financial indicators formation for this type of product.

\section{Materials and methods}

The quality of financial results management largely determines the effective operation of enterprises and business organizations, their stable performance and competitiveness in modern economic conditions [4].

Currently, the most common among the main methods of managing the financial results of an organization are: factor analysis; planning and forecasting profits, including on the basis of economic and mathematical modeling; distribution of profits; profit management based on the organization of responsibility centers $[5,6]$.

Financial forecasting is used to identify real prospects for the development of the financial sector of the enterprise, as well as for the purpose of scientific justification of the planned volumes and directions of spending financial resources [7].

Economic and mathematical modeling is most in demand in business process management. The demand is explained by the simplicity of application and reliability of the results obtained, which can be taken into account when predicting the company's financial results. At the same time, the use of economic and mathematical modeling leads to the sorting of information and analytical support for management processes: certain requirements for the composition of information, methods of its storage and analysis are formulated and implemented [8].

\section{Results and discussion}

In order to forecast costs, it is necessary to determine the need for basic resources for sugar beet cultivation. The need for arable land, fertilizers, fuel and lubricants, sugar beet seeds, protective equipment, and monetary costs can be determined using an economic and mathematical model $[9,10]$.

For the same enterprise, different options for optimization of production and production costs are used, which also give the corresponding economic effect. Decision-making on the choice of an option to optimize the production and cost of sugar beet in Pachelmskoe Khozyaistvo LLC will be carried out using an economic and mathematical model.

The stages of implementation of the economic and mathematical model for optimizing the cost of production in Pachelmskoe Khozyaistvo LLC are as follows:

1. Formulation of the optimization problem and the optimality criterion - the minimum cost of production.

2. Determination of the necessary list of variables and restrictions when solving the problem of product cost optimization.

3. Selection of technical and economic coefficients and collection of model data that determine the mathematical recording of product cost optimization.

4. Composing and solving a model numerical matrix.

5. Analysis of the results obtained, their adjustment in accordance with the task, if necessary.

Variables and model constraints are accepted in accordance with the task at hand. When forming a model of product cost optimization, a system of thirteen variables was formed. The minimum cost of sugar beet production is defined as the target function. 
The results of calculations showed that Pachelmskoe Khozyaistvo LLC can count on the volume of sugar beet production in $1680725 \mathrm{c}$ at a cost of 275293 thousand rub.

Table 2 presents the result of optimal decisions to changes in the cost of $1 \mathrm{c}$ of sugar beet with the use of economic-mathematical model which shows that by optimizing the product unit cost compared to 2019 reduced by 130 rub., or more than twice.

Table 2. Results of the optimal solution for changing the cost of $1 \mathrm{c}$ of sugar beet, taking into account the use of an economic and mathematical model for Pachelmskoe Khozyaistvo LLC.

\begin{tabular}{|l|c|c|c|}
\hline \multicolumn{1}{|c|}{ Cost name } & $\begin{array}{c}\text { Actual value } \\
\mathbf{( 2 0 1 9 )}\end{array}$ & $\begin{array}{c}\text { Planned value } \\
\text { using OMM }\end{array}$ & $\begin{array}{c}\text { Deviation of the } \\
\text { planned value } \\
\text { from the actual } \\
\text { value }\end{array}$ \\
\hline Sown area, ha & 3066 & 3066 & 0 \\
\hline Volume of sugar beet production, c & 1559336 & 1680725 & 121389 \\
\hline Product yield from 1 ha, c & 515 & 603 & 89 \\
\hline Total cost, thousand rub. & 290412 & 275293 & -15119 \\
\hline $\begin{array}{l}\text { Wages with deductions for social needs, } \\
\text { thousand rub. }\end{array}$ & 35332 & 32224 & -3108 \\
\hline Seeds and planting material, thousand rub. & 22052 & 21830 & -222 \\
\hline Mineral fertilizers, thousand rub. & 33549 & 30353 & -3196 \\
\hline $\begin{array}{l}\text { Chemical plant protection products, } \\
\text { thousand rub. }\end{array}$ & 28919 & 27901 & -1018 \\
\hline Electricity, thousand rub. & 1861 & 1564 & -297 \\
\hline Oil products, thousand rub. & 32369 & 31610 & -759 \\
\hline Maintenance of fixed assets, thousand rub. & 31384 & 31365 & -19 \\
\hline Other expenses, thousand rub. & 104946 & 104946 & 0 \\
\hline
\end{tabular}

It should be noted that the reduction of sugar beet cost is planned to be carried out through the following measures:

1. Sugar beet will be grown on the area where cereals (wheat and barley) were previously grown, as the best precursors of sugar beet.

2. The use of modern industrial technologies, in particular, increase of plant density, i.e. increase of the number of seeds per hectare, which is one of the features of modern technology of sugar beet cultivation, and this will increase the sugar beet yield.

3 . To use sugar beet varieties with higher yields when sowing.

Based on the data obtained, we will forecast the financial results of Pachelmskoe Khozyaistvo LLC for 2020-2023. Figure 2 shows the algorithm for calculating the forecast of financial results. 


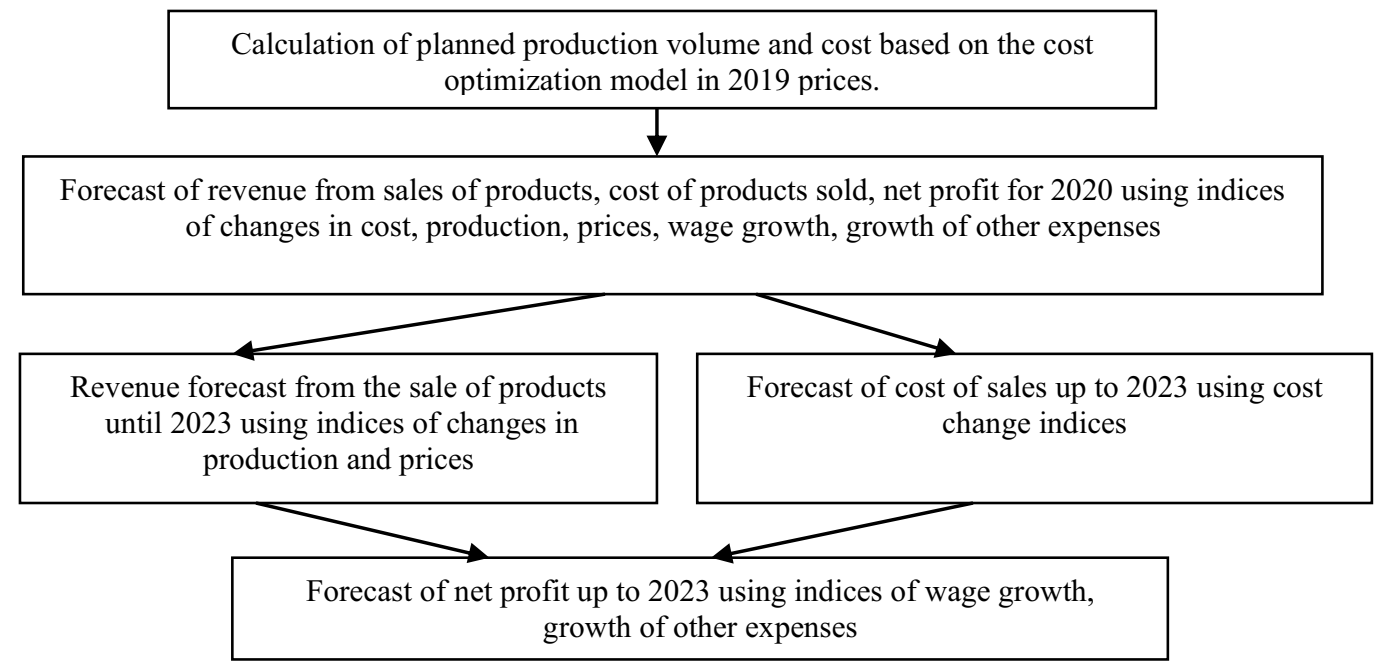

Fig. 2. Algorithm for calculating the forecast of financial results.

To calculate the profit planned for 2020, using the above data based on the indicators of 2019 , it is necessary to use the price index for agricultural products, the index of agricultural production, the prime cost index, the index of growth of wages, the index of growth of other expenses.

Table 3 shows the dynamics of the main indices calculated using the method of the Russian Academy of Agricultural Sciences and scientists of the All-Russian Research Institute of Agricultural Economics.

Table 3. Dynamics of price indices.

\begin{tabular}{|l|c|c|c|c|}
\hline \multicolumn{1}{|c|}{ Index } & $\mathbf{2 0 2 0}$ & $\mathbf{2 0 2 1}$ & $\mathbf{2 0 2 2}$ & $\mathbf{2 0 2 3}$ \\
\hline The index of the cost of agricultural products & 108 & 103.7 & 109.4 & 108.6 \\
\hline Index of agricultural production & 111.8 & 102.4 & 103 & 102.7 \\
\hline Price index for agricultural products & 109.3 & 105.2 & 105 & 104.8 \\
\hline Wage growth index & 122.6 & 112.1 & 115 & 119.7 \\
\hline Other expenses growth index & 120.3 & 101 & 106.8 & 104.3 \\
\hline
\end{tabular}

The planned net profit of Pachelmskoe Khozyaistvo LLC in 2020 will be 836720 thousand rub.

Forecast reports on financial results for 2021, 2022, and 2023 were compiled using agricultural product price indices, agricultural production indices, cost indices, wage growth indices, and other expenses growth indices.

According to the forecast report on financial results in Pachelmskoe Khozyaistvo LLC for 2021 , the growth rate of revenue will be $107.7 \%$, the growth rate of net profit $-123.6 \%$. The company's profitability will increase by 4.8 percentage points - from $26.2 \%$ in 2020 to $31 \%$ in 2021.

Analysis of data from the forecast report on financial results for 2022 at Pachelmskoe Khozyaistvo LLC shows that the revenue growth rate will be $107.7 \%$, and the net profit growth rate will be $123.4 \%$. The company's profitability will increase by 5.1 percentage points.

According to the forecast report on financial results for 2023, the revenue growth rate will be $125.4 \%$, and the net profit growth rate will be $186.1 \%$. The company's profitability will increase by $21.1 \%$.

Table 4 shows the dynamics of the forecast financial results of Pachelmskoe Khozyaistvo LLC as a whole, which reflects the positive growth of the company's net profit. 
Table 4. Dynamics of forecasting financial results of Pachelmskoe Khozyaistvo LLC.

\begin{tabular}{|c|c|c|c|c|}
\hline \multirow{2}{*}{ Factor (indicator) } & \multicolumn{4}{|c|}{ Value of indicator } \\
\hline & 2020 & 2021 & 2022 & 2023 \\
\hline Revenue, thousand rub. & 4613903 & 4970318 & 5354265 & 6716690 \\
\hline Cost of sales, thousand rub. & 3643966 & 3778793 & 3918608 & 4255608 \\
\hline Gross profit, thousand rub. & 969937 & 1191525 & 1435657 & 2461081 \\
\hline Management expenses, thousand rub. & -16456 & -18431 & -20642 & -24709 \\
\hline Profit from sales, thousand rub. & 953481 & 1173094 & 1415014 & 2436372 \\
\hline Interest receivable, thousand rub. & 32246 & 35471 & 35825 & 37366 \\
\hline Interest payable, thousand rub. & -420631 & -462694 & -467321 & -487416 \\
\hline Other income, thousand rub. & 443860 & 478147 & 515083 & 646149 \\
\hline Other expenses, thousand rub. & -171895 & -189085 & -190975 & -199187 \\
\hline Profit before tax, thousand rub. & 837061 & 1034934 & 1307627 & 2433284 \\
\hline Net profit, thousand rub. & 836720 & 1034593 & 1307286 & 2432943 \\
\hline Profitability of sales, $\%$ & 19.2 & 23.6 & 26.4 & 36.3 \\
\hline Profitability of operations, $\%$ & 23.0 & 27.4 & 33.4 & 57.2 \\
\hline
\end{tabular}

Figure 3 shows the dynamics of the main financial indicators of Pachelmskoe Khozyaistvo LLC, taking into account the forecast made until 2023. A well-defined positive dynamics of all indicators is clearly visible here.

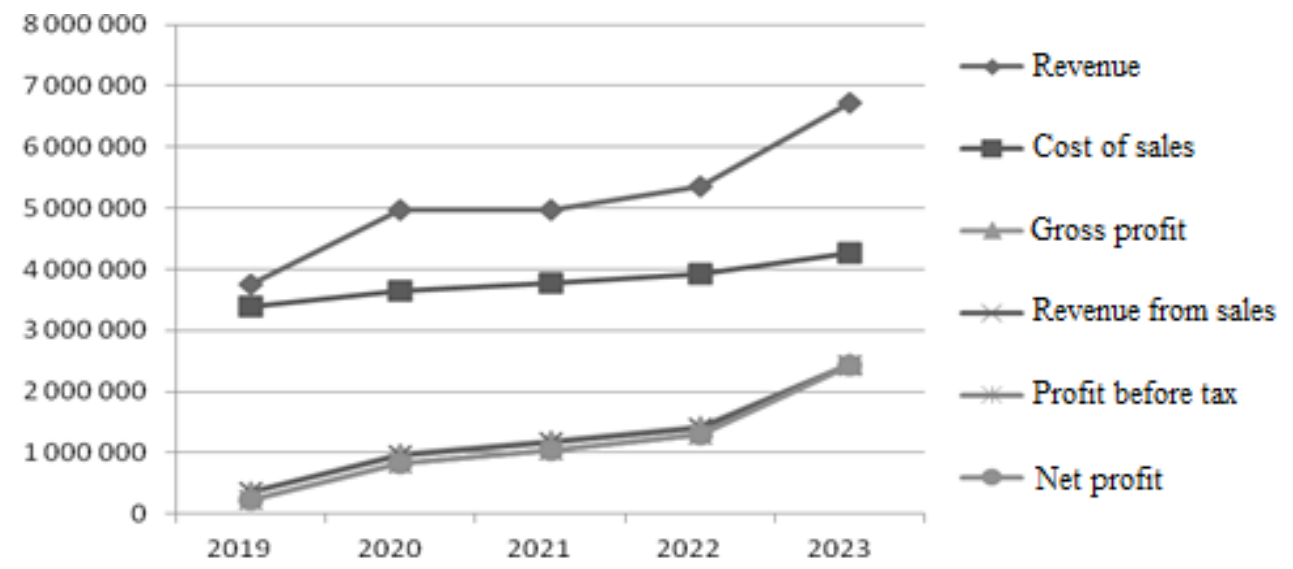

Fig. 3. Dynamics of main financial indicators of Pachelmskoe Khozyaistvo LLC for 2019-2023, thousand rub.

The dynamics of the main indicators of profitability, shown in figure 4, also reflects a significant improvement in the financial condition of Pachelmskoe Khozyaistvo LLC. 


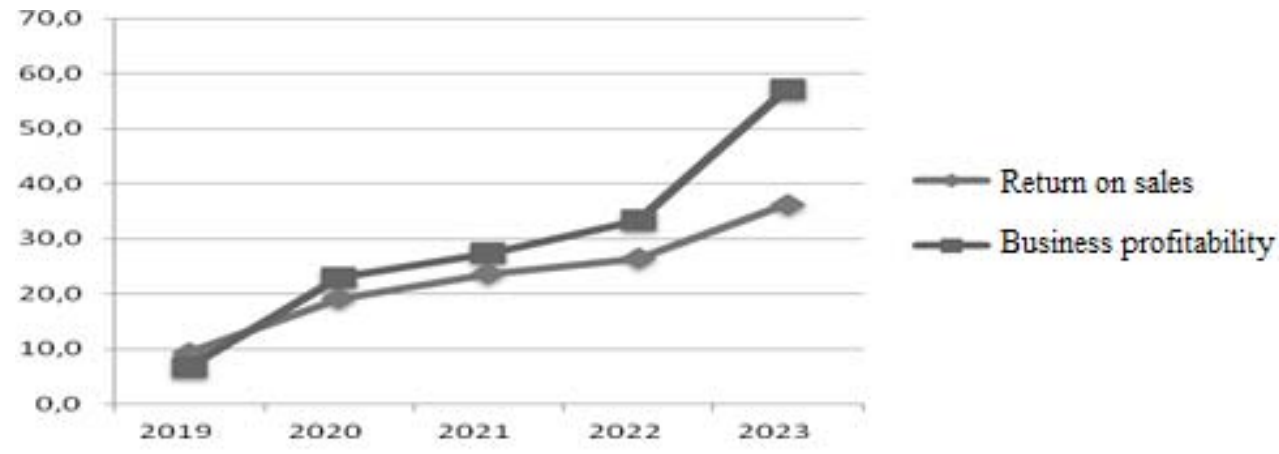

Fig. 4. Dynamics of the main indicators of profitability, \%.

Thus, the results of the study show that Pachelmskoe Khozyaistvo LLC has every reason to expect a stable profit in the future until 2023 inclusive.

Achieving the forecast indicators of financial and economic activity in 2020-2023 will improve the balance sheet structure and, accordingly, determine the direction of spending its own resources not only to finance current activities, but also to pay dividends, as well as strategic goals, such as the development of new areas of activity, expansion of production, updating of production assets, etc. [11,12].

\section{Conclusions}

1. With the purpose of improving the management of financial results the main factors are identified influencing the profit margin, namely the increase in sales, decrease its costs, change in the structure of sales, development of pricing policies.

2. Analysis of the dynamics of revenue, gross profit and cost price showed an increase in costs in the revenue of the studied company, therefore, reserves for increasing profits should be sought not in increasing sales volumes, but in reducing the cost of production.

3. The type of products that have a good potential to increase profits was identified. Based on the analysis of the dynamics of changes in the main production indicators, the initial data were formed for the formation of an economic and mathematical model for forecasting the company's financial results, taking into account changes in the current production parameters of this type of product.

4. Analysis of the optimal solution to change the cost of sugar beet cultivating, taking into account the use of an economic and mathematical model, showed that as a result of optimization, the cost of a unit of production is reduced by 22.4 rub. compared to 2019.

5. Based on the data obtained, as well as indices calculated using the method of the Russian Academy of Agricultural Sciences and scientists of the All-Russian Research Institute of Agricultural Economics the forecast profit for the period 2020 - 2023 was calculated, forecast reports on financial results were prepared, according to which the company can receive a stable profit and significantly improve the balance sheet structure.

6. The results of the study showed that Pachelmskoe Khozyaistvo LLC will be able to improve its financial condition in the future, taking into account the calculated profit forecast and maintaining its positive dynamics.

\section{References}

1. http://investinpenza.com/About/Economy 
2. E. Pozubenkova Digitalization of agriculture Sursky Bulletin. 2 (10), 75-78 (2020)

3. http://pnzreg.ru/branches/ekonomika/

4. A. Dudareva, E. Efremova Management system of financial results of the organization Agricultural sector of the Russian economy: experience, problems and development prospects, 293-298 (2020)

5. N. Baryshnikov. D. Murzin, D.Samygin Forecasting bankruptcy models for agrarian business. International scientific and practical Conference on agrarian economy in the era of globalization and integration, 1-9 (2018)

6. T Stojanović, S. Stojanović Finansijska analiza položaja preduzeća iz poljoprivrednog sektora Republike Srpske. Agroznanje. 16(4), 549-557 (2015)

7. M. Lukyanova, L. Asylbayeva Financial result of the enterprise as an object of assessment and analysis Socio-economic problems of development of the agricultural sector of the economy and ways to solve them, 164-168 (2015).

8. D. Samygin, N. Baryshnikov, L. Vinnichek, I. Glasunov Strategic models of optimization of support of farmers Ponte,146-157 (2017)

9. D. Samygin, N. Baryshnikov, L. Misyurkina Model of scenario planning the development of agriculture in the region Economy of the region. 15, 865-879 (2019)

10. N. Bondina, I. Bondin, O. Lavrina Methods for evaluating the effectiveness and efficiency of agricultural production Agricultural scientific journal, 68-73 (2015)

11. O. Tagirova, A. Nosov, O. Novichkova, M. Fedotova, T. Boryaeva Income generation and distribution of profits in the agricultural organizations. Audit and financial analysis. 2, 242-246 (2017)

12. O. Novichkova, M. Fedotova Assessment of factors affecting the company's performance Audit and financial analysis. 5-6, 262-268 (2017) 